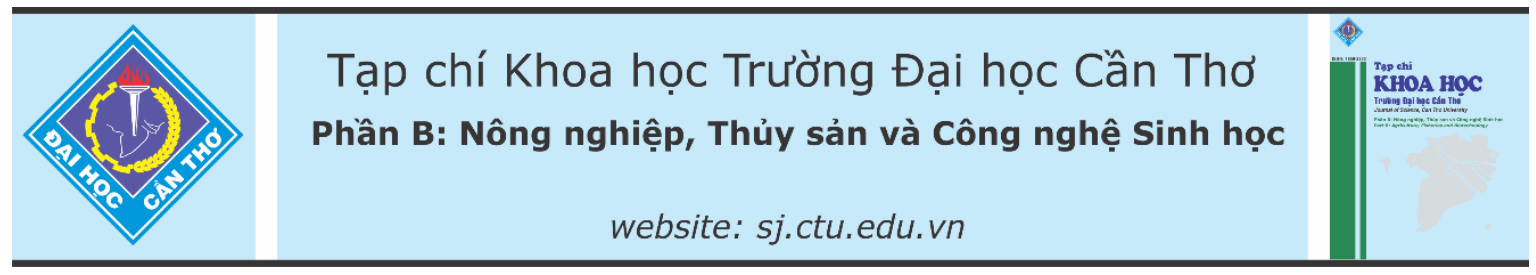

DOI:10.22144/ctu.jvn.2021.124

\title{
CÁC BIẾN THỂ GENE OSTZF1 LIÊN QUAN ĐẾN KHẢ NĂNG CH!̣U MậN Ở GIỐNG LÚA ĐỐC PHỤNG BẰng PHƯƠNG PHÁP GIẢI TRÌNH TỰ Bộ GENE
}

Huỳnh Kỳ ${ }^{1 *}$, Trần Đặng Thành Phát ${ }^{1}$, Nguyễn Thị Kim Phụng ${ }^{1}$, Văn Quốc Giang ${ }^{1}$, Nguyễn Văn Mạnh ${ }^{1}$, Trần In Đô ${ }^{1}$, Nguyễn Thành Tâm ${ }^{2}$, Nguyễn Châu Thanh Tùng ${ }^{1}$, Nguyễn Lộc Hiền ${ }^{1}$ và Huỳnh Như Điền ${ }^{1}$

${ }^{1}$ Khoa Nông nghiệp, Trường Đại học Cần Tho

${ }^{2}$ Viện Nghiên cưu Phát triển Đồng bằng sông Cửu Long, Truờng Đại học Cần Tho

*Nguoòi chịu trách nhiệm về bài viết: Huỳnh Kỳ (email: hky@ctu.edu.vn)

\section{Thông tin chung:}

Ngày nhận bài: 06/02/2021

Ngày nhận bài sứa: 12/04/2021

Ngày duyệt đăng: 20/08/2021

Title:

Variation of OsTZF1 gene related to salt tolerance in Doc Phung rice variety using whole geneome sequencing

\section{Tù khóa:}

Đốc Phụng, gải trình tụ bộ gene, InDel, SNP

\section{Keywords:}

Doc Phung, InDel, SNP and Whole geneome sequencing

\begin{abstract}
In this study, the next generation sequencing technology was used to resequence the geneome of Doc Phung rice varieties (salt-tolerant variety) and Nep Mo (salt-susceptible variety) to identify functional markers that are involved in salt tolerance mechanisms in Doc Phung rice variety. In comparision with the reference geneome, the result showed that Doc Phung geneome was consisted of 1,918,726 variations of SNP and 163.409 InDels (81,435 insertions, and 81,974 deletion). Whereas in Nep Mo variety, there were 1,931,380 SNPs and 171.663 InDels (88,473 insertions and 83,190 deletion). Most of the variants are located in non-functional regions including upstreams, downstream, and intergeneic, accounting for over $75 \%$. The variation of OsTZF1 (LOC Os05g10670.1) gene that regulates the expression of those gene related to biological and abiotic stress factors, showed that there were 7 SNPs and 9 nucleotides insertion (encode 3 amino acid arginine) in Doc Phung variety when being compared to Nep Mo based on reference geneome. This information will help the breeders to apply as a molecular marker, using salt-tolerant rice breeding program in the future.
\end{abstract}

\section{TÓM TẮT}

Trong nghiên cưu này, kỹ thuật giải trình tư thế hệ mới (next generation sequencing) được uúng dụng để giải trình tự của bộ gene 2 giống lúa Đốc Phưng (giống chông chịu mặn) và giống Nếp Mớ (giống mẫn cảm với mặn), nhằm tìm các chỉ thị phân tử là gene chức năng mà các gene này liên quan đến co chế chống chịu mặn có trong giống lúa Đốc Phung. Kết quả so sánh với bộ gene tham chiếu, bộ gene của giống lúa Đốc Phụng có khoảng 1.918 .726 biến thể dạng thay đổi một nucleotide (Single Nucleotide Polymorphism) và và chèn vào khoảng 81.435, mất đi khoảng 81.974. Trong khi đó ở giống Nếp Mõ̃, có khoảng 1.931.380 SNP và chèn vào khoảng 88.473 , mất đi khoảng 83.190 vùng $D N A$. Đa số các biến thể xuất hiện ở các vùng không mang chức năng nhu truơớc sau và giữa các gene chiếm tỉ lệ trên $75 \%$. Kết quả khảo sát biến thể xuất hiện trong vùng gene OsTZF1 (LOC Os05g10670.1), có chức năng điều hòa các nhóm gene liên quan đến các yếu tố stress sinh học và phi sinh học, cho thấy ở giống Đốc Phưng có 7 biến thể SNP và có chèn thêm 9 nucleotide mã hóa 3 amino acid arginine khi so với giống Nếp Mỡ dụa trên bộ gene tham chiếu. Thông tin này giúp cho các nhà chọn giống sử dụng nó nhu chi thị phân tử, chọn tạo giống chống chịu mặn trong tuoong lai. 


\section{GIỚI THIỆ}

Lúa (Oryza sativa L.) là cây trồng quan trọng trên thế giới, được trồng trên nhiều quốc gia, cung cấp lương thực chính cho $50 \%$ dân số trên thế giới (Khush, 1997; Islam et al., 2018) và có tính thương mại. Tuy nhiên, trước thực trạng của biến đổi khí hậu, hạn hán, xâm nhập mặn đã và đang là vấn đề cấp bách ảnh hưởng đển sản lượng lúa gạo, đặc biệt tác động nặng nề đến nền nông nghiệp Việt Nam, Đồng bằng sông Cửu Long (Nguyễn Thanh Tường và ctv., 2011), các tỉnh ven biển chịu sự xâm nhập mặn và ngập ngày càng gia tăng làm thay đổi đất canh tác lúa sang các vùng nuôi trồng thủy sản nước lợ (Phạm Thanh Vũ và ctv., 2016). Nhằm đảm bảo an ninh lương thực, việc canh tác giống lúa trên nền đất bị nhiễm mặn và đảm bảo sản lượng là cần thiết. Do đó, việc chọn tạo và khai thác nguồn gene lúa có khả năng chống chịu trong điều kiện đất nhiễm mặn đã và đang được các nhà khoa học quan tâm.

Khai thác và sử dụng nguồn gene lúa địa phương, ở những vùng bị xâm nhiễm mặn là một trong những chiến lược mà các nhà chọn tạo giống ưu tiên (Menguer et al., 2017; Rahman et al., 2016), tuy nhiên chiến lược này đôi khi không thành công vì nguồn gene lúa có khả năng chống chịu mặn không mang lại năng suất, hoặc phụ thuộc rất nhiều vào thời vụ và thường thì chất lượng gạo không cao (Rahman et al., 2016). Vì vậy, có rất nhiều báo cáo đã khai thác thông tin của bộ gene từ các giống lúa địa phương trong công tác chọn tạo giống lúa chịu mặn (Lakra et al., 2019; Subudhi et al., 2020; Yuan et al., 2020). Ngày nay với tiến bộ của khoa học công nghệ, kỹ thuật giải trình tự thế hệ mới (Next Generation Sequencing-NGS) đã phát triển mạnh mẽ giúp cho việc khai thác thông tin di truyền một cách nhanh chóng, hiệu quả và hỗ trợ cho công tác chọn tạo giống dựa trên nền tảng dấu chỉ thị phân tử (Barba et al., 2014). Bằng việc sử dụng kỹ thuật NGS đã xây dựng bộ gene tham chiếu trên cây lúa một cách hoàn chỉnh và chính xác hơn (Kawahara et al., 2013), từ cở sở đó đã giúp cho cung cấp thông tin về các đa hình khi sử dụng bộ gene tham chiếu để so sánh các bộ gene cần nghiên cứu (Huang et al., 2013). Thực vậy, việc phát hiện ra các biến thể trên toàn bộ bộ gene tạo cơ hội để làm sáng tỏ cơ sở phân tử của sự khác biệt kiểu hình, đặc biệt là các biến thể giúp cho cây trồng có khả năng chống chịu lại với các điều kiện bất lợi của môi trường. Trên cơ sở đó, nghiên cứu này đã ứng dụng công nghệ NGS để giải mã bộ gene của 2 giống lúa địa phương vùng Đồng bằng Sông Cửu Long (ĐBSCL) 1 giống có khả năng chịu mặn và 1 giống mẫn cảm với mặn nhằm tìm ra các biến thể ở các gene mang tính chống chịu mặn đã được xác định từ các nghiên cứu trước (Jain et al., 2014; Chen et al., 2017), từ đó có thể sử dụng chúng như các chỉ thị phân tử dùng cho chọn giống chống chịu mặn trong tương lai.

\section{PHƯƠNG TIÊN VÀ PHƯƠNG PHÁP}

\subsection{Phương tiện}

Hai giống lúa địa phương có kiểu hình tương phản được dùng trong thí nghiệm này là Đốc Phụng (chống chịu mặn) và Nếp Mỡ (mẫn cảm mặn) được lấy từ ngân hàng giống của Khoa Nông nghiệp, Trường Đại học Cần Thơ. Hai giống lúa Đốc Phụng và Nếp Mỡ được lựa chọn cho nghiên cứu dựa trên kết quả từ nghiên cứu của Tam (2019) và Tin et al. (2021) về tính chống chịu cũng như mẫn cảm với mặn.

\subsection{Phương pháp}

\subsubsection{Phwơng pháp phân lập và giải trình tự $D N A$}

DNA của 2 giống lúa dùng cho nghiên cứu được ly trích theo quy trình Doyle (1990), sau khi ly trích thành công, DNA được kiểm tra chất lượng bằng Nanodrop (Thermofisher, USA) và Bioanalyzer (Agilent, USA). Sau đó mẫu được đưa giải trình tự bằng hệ thống Illumina HiSeq $2500^{\mathrm{TM}}$ sử dụng kỹ thuật giải trình tự 100-bp từ hai đầu theo quy trình của chuẩn của Illumina (Illumina, San Diego, $\mathrm{CA}$ ).

\subsubsection{Phân tích bộ gene}

Hầu hết các bước phân tích được thực hiện trên nền Linux Ubuntu 18.04.3 LTS (https://ubuntu.com/ download/desktop). Sử dụng chương trình fastp V0.20.0 như một bộ tiền xử lý file FASTQ để kiểm tra chất lượng và các tính năng lọc dữ liệu, chương trình này chạy nhanh hơn 2-5 lần các so với các chương trình xử lý khác như Trimmomatic hay Cutadapt (Chen et al., 2018). Những trình tự được đọc sau khi được kiểm tra chất lượng được gắn vào bộ gene tham chiếu Os-Nipponbare-ReferenceIRGSP-1.0 (Kawahara et al., 2013) có trên Ensembl Plants website (Bolser et al., 2016) bằng cách sử dụng phần mềm HISAT2 V2.1.0 (Kim et al., 2015; Keel \& Snelling, 2018), và loại bỏ hoàn toàn các low-mapping quality $(\mathrm{MAPQ}<30)$ bằng công cụ SAMtools toolkit V1.9 (Li et al., 2009). Để nhận dạng các biến thể, các lỗi trùng lặp (duplicates) được loại bỏ khỏi file đã được điều chỉnh bằng công cụ Picard V2.18.7 (http://broadinstitute.github.io/ picard/).

\subsubsection{Xác định biến thể (variant calling)}

Sau khi loại bỏ các lỗi do trùng lắp gây ra và sắp xếp lại các vùng xung quanh InDels, sau đó sử dụng 
chương trình SAMtools toolkit V1.9 (Li et al., 2009) và $\mathrm{BCF}$ tools $\mathrm{V} 1.9$ (Li, 2011) cho việc phát hiện biến thể SNPs, InDels. Tiếp theo, loại bỏ các biến thể được dò tìm có chất lượng thấp $(\% \mathrm{QUAL}<20)$, chỉ giữ lại các biến thể có chất lượng cho các phân tích sâu hơn bằng công cụ $\mathrm{BCFtools} \mathrm{V1.9} \mathrm{(Li,} \mathrm{2011).}$ Theo Li (2014), việc loại bỏ các biến thể bị trùng lắp (overlapping) cùng với sự xuất hiện của các vùng low-mapping sẽ mang lại hiệu quả cao trong việc loại bỏ các dị hợp tử giả (heterozygotes). Ngoài ra, đối với các vị trí có độ nhiễu cao (low-complexity) sẽ được đánh dấu là DUST (Morgulis et al., 2006) chúng được loại bỏ bằng công cụ minimap toolkit V0.2 (https://github.com/lh3/minimap) (Li, 2016; Chu et al., 2017).

\subsubsection{Phân tích số liệu}

Sử dụng chương trình IGV (integrative geneome viewer) truy cập tại trang web Integrative Geneome Viewer (https://www.igv.org) để kiểm tra và so sánh những biến thể đột biến chèn hoặc mất đoạn (InDels) giữa các mẫu so với bộ gene tham chiếu
Nipponbare phiên bản 7.0 (Robinson et al., 2011; Thorvaldsdóttir et al., 2013) và so với các giống với nhau ở các vùng Quantitative Trait Locus (QTL) liên quan đến khả năng chống chịu mặn đã được Naveed et al. (2018) tìm thấy, từ đó để cho thấy sự khác biệt trình tự protein giữa giống chống chịu và giống mẫn cảm.

\section{KẾT QUẢ VÀ THẢO LUẬN}

\subsection{Kết quả đọc và ghép vào bộ gene tham chiếu}

Kết quả giải trình tự bộ gene của 2 giống lúa thí nghiệm bằng kỹ thuật giải trình tự thế hệ mới thông qua hệ thống Illumina HiSeq $2500^{\mathrm{TM}}$ thu được số lượng đọc sau khi loại bỏ các lần đọc có chất lượng thấp hơn $30 \%$ tương ứng là 25.288 .216 bp cho Đốc Phụng và 27.352.488 bp cho Nếp Mỡ (Bảng 1). Tỉ lệ đọc được ghép hoàn chỉnh vào bộ gene Nipponbare đạt khoảngg từ $65 \%-67 \%$ của 2 giống lúa.

Bảng 1. Số liệu của 3 giống lúa được giải trình tự

\begin{tabular}{lrrrrr}
\hline Giống lúa & $\begin{array}{r}\text { Số liệu read thô } \\
\text { (bp) }\end{array}$ & $\begin{array}{r}\text { Số liệu read } \\
\text { (MAPQ30) }\end{array}$ & $\begin{array}{r}\text { Số liệu read } \\
\text { được ghép (bp) }\end{array}$ & $\begin{array}{r}\text { Tỉ lệ read } \\
\text { được ghé (\%) }\end{array}$ & $\begin{array}{r}\text { Chiều dài của } \\
\text { read thô (bp) }\end{array}$ \\
\hline Đốc Phụng & 37.948 .246 & 25.288 .216 & 25.586 .354 & 67,42 & $150 * 2$ \\
Nếp Mớ & 41.837 .368 & 27.352 .488 & 26.602 .508 & 65,87 & $150 * 2$ \\
\hline
\end{tabular}

MAPQ30: Mapping quality of 30

\subsection{Nhận dạng SNPs và InDels}

Qua phân tích kết biến thể di truyền gồm đột biến điểm thay đổi nucleotide (SNPs) và đột biến mất hay chèn nucleotide (InDels) giữa 2 giống lúa dựa trên bộ gene tham chiếu Nipponbare thu được tổng số SNP khoảng 1.918.726 và chèn vào khoảng 81.435 , mất đi khoảng 81.974 ở giống Đốc Phụng. Trong khi đó ở giống Nếp Mỡ có khoảng 1.931.380 SNP và chèn vào khoảng 88.473 , mất đi khoảng 83.190 (Bảng 2). Mật độ xuất hiện các loại biến thể trung bình trong $100 \mathrm{~kb}$ cho SNP khoảng 515 và 518 , tương ứng cho Đốc Phụng và Nếp Mỡ. Mật độ xuất hiện cho Indel ở 2 giống này trong vùng $100 \mathrm{~kb}$ tương ứng 45 (Đốc Phụng) và 46 (Nếp Mỡ). Kết quả nghiên cứu này cũng tương ứng như kết quả tìm thấy khi so sánh bộ gene của hai giống lúa hoang của Trung Quốc với bộ gene tham chiếu Nipponbare và 93-11 (Liu et al., 2017), và cũng được tìm thấy khi nghiên cứu bộ gene của 1.143 dòng lúa lai có nguồn gốc từ các bố mẹ ưu tú ở Trung Quốc ( $\mathrm{Lv}$ et al., 2020).

Bảng 2. Số liệu SNPs và InDels của 2 giống lúa

\begin{tabular}{lrrrrrr}
\hline \multirow{2}{*}{ Giống lúa } & \multicolumn{3}{c}{ SNP } & \multicolumn{4}{c}{ InDel } \\
\cline { 2 - 7 } & Tổng số & Mật độ SNPs/100 kb & Chèn & Xóa & Tổng số & Mật độ InDels/100 kb \\
\hline Đốc & 1.918 .726 & 515 & 87.435 & 81.974 & 169.409 & 45 \\
Phụng & 518 & 88.473 & 83.190 & 171.663 & 46 \\
Nếp Mỡ & 1.931 .380 & & &
\end{tabular}

Sự phân bố của các đa hình DNA xuất hiện trong suốt 12 nhiễm sắc thể (NST) của 2 giống lúa (Hình 1). Phần lớn số lượng SNPs và InDels của mỗi NST được tìm thấy tỉ lệ thuận với chiều dài của NST đó trên cả Đốc Phụng và Nếp Mỡ. Hầu hết SNPs được phát hiện nhiều ở NST $1,2,3$ và InDels phổ biến nhiều nhất ở NST 2 và 3 . Tuy nhiên, các đa hình DNA đều xuất hiện ít ở NST 9,10 và 12 . Bên cạnh đó, số lượng biến thể SNPs và InDels của Nếp Mỡ chiếm cao hơn so với Đốc Phụng. 


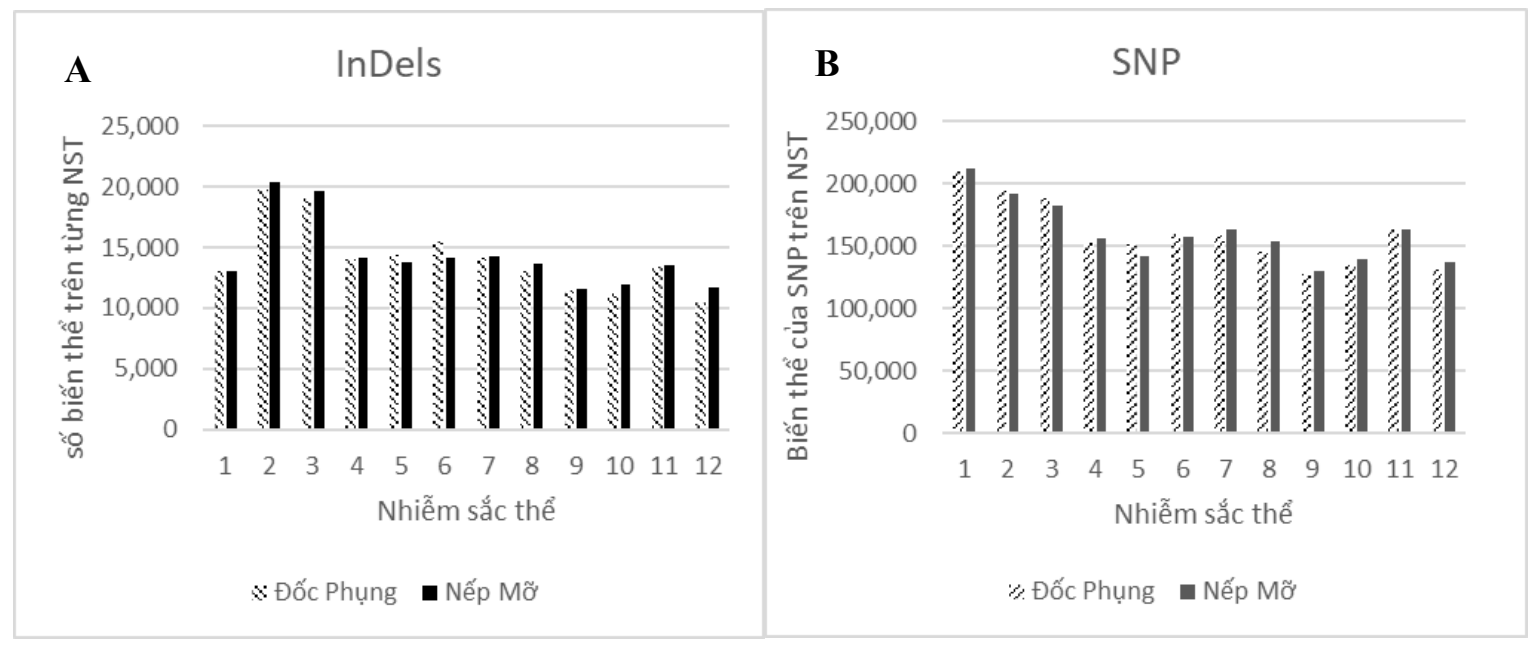

\section{Hình 1. Đa hình DNA trên 12 NST của ở các giống Đốc Phụng và Nếp Mõ}

A. Indel, B. SNP

\subsubsection{Phân tích SNPs và InDels}

Tổng số đột biến đồng vị (transition -Ts) và đột biến chuyển vị (transversion- Tv) của 2 giống được trình bày trong Hình 2 . Tần số của các $T s(\mathrm{~A} / \mathrm{G}$ và $\mathrm{C} / \mathrm{T})$ ở Đốc Phụng, Nếp Mỡ tương tự nhau và đều cao hơn so với tần số $\mathrm{Tv}(\mathrm{A} / \mathrm{C}, \mathrm{A} / \mathrm{T}, \mathrm{C} / \mathrm{G}$ và $\mathrm{G} / \mathrm{T})$. Tần số $\mathrm{A} / \mathrm{G}$ và $\mathrm{C} / \mathrm{T}$ tương tự nhau trong mỗi giống (Hình 2A). Tuy nhiên, tần số của Tv không đồng đều, tần số của $\mathrm{G} / \mathrm{C}$ thấp hơn so với ba loại Tv khác. Tỉ lệ Ts/Tv của Nếp Mỡ (2.617) cao hơn so với Đốc Phụng (2.593) (Hình 2B), tỉ lệ Ts/Tv được báo cáo trên lúa và ngô (Batley et al., 2003; Morton, 1995), tần số đột biến của Ts cao hơn so với Tv (thay đồi cùng dạng vòng sẽ mang nhiều lợi thế hơn) và khả năng thay đổi cấu trúc và chức năng protein của $T s$ sẽ thấp hơn so với Tv (Wakeley, 1996; Subbaiyan et al., 2012). Như vậy, với tỉ lệ Ts/Tv càng thấp thì khả năng đột biến có ảnh hưởng lên protein càng lớn, với kết quả này thì giống Đốc Phụng có khả năng biến đổi do đột biến cao hơn Nếp Mỡ.

Một trong những đặc điểm quan trọng của đột biến là vị trí của đa hình DNA vì được biết có ảnh hưởng đến sự biểu hiện và chức năng gene (Subbaiyan et al., 2012; Subudhi et al., 2020). Các đa hình DNA xuất hiện trong vùng mã hóa là rất quan trọng vì chúng có thể làm thay đổi chức năng của protein, các biến thể xuất hiện trong vùng enhancer có thể làm giảm hay kìm hãm sự biểu hiện gene. Do đó, việc phát hiện ra các đa hình liên quan đến sự thay đổi chức năng của gene là rất quan trọng để nghiên cứu về sự khác biệt của các kiểu hình (Jain, 2012; Jain et al., 2014). Nhìn chung, sự phân bố của SNPs và InDels ở các vùng gene khác nhau có tî̉ lệ tương đương cho các so sánh của 2 giống. SNPs và InDels xuất hiện nhiều ở các vùng không mã hóa (bao gồm các vùng giữa (intergeneic), trên (upstream), dưới (downstream) các gene) so với các vùng mã hóa $(\mathrm{CDS})$ (Hình 3). Tần suất của các đột biến di truyền xuất hiện nhiều ở các vùng không mã hóa có thể do chịu áp lực ít hơn từ chọn lọc tự nhiên (Barreiro et al., 2008). Cụ thể, các đa hình DNA xuất hiện nhiều nhất trong vùng upstream và downstream chiếm tỉ lệ gần bằng và hơn $30 \%$, tiếp đến là vùng intergeneic đạt hơn $21 \%$ và $16 \%$ lần lượt cho các biến thể SNPs và InDels, vùng intron đạt khoảngg $3,1-4,4 \%$, trong khi đó vùng mã hóa chỉ chiếm tỉ lệ khoảngg 1,6-2,9\%, cuối cùng gồm các vùng exon, $5^{\prime}$ UTR và $3^{\prime}$ UTR có tỉ lệ thấp nhất chỉ khoảngg $0,4-$ 1,1\% (Hình 3). 


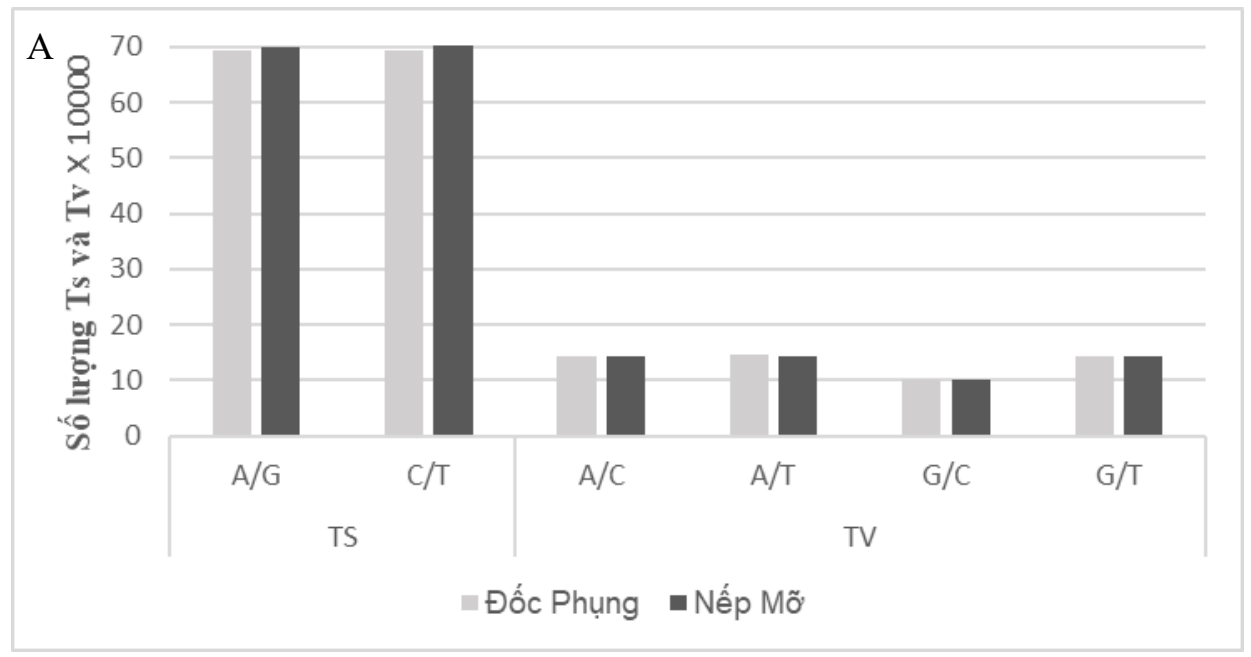

B

Ts/Tv

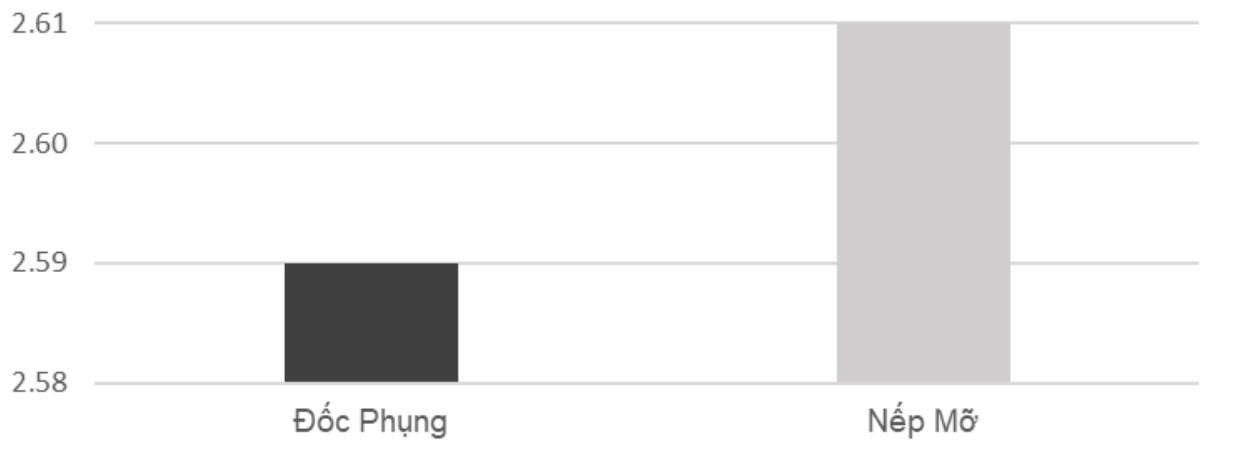

Hình 2. Phân loại biến thể ở hai giống lúa Đốc Phụng và Nếp Mõ

A. số luợng loại biến thể $T s$ và $T v$; $B$. Tỉ lệ biến thể $T s / T v$

Các biến thể xảy ra bên ngoài vùng mã hóa cũng có khả năng tác động đến sự biểu hiện của gene như đột biến ở vùng promoter, các vị trí ghép nối các exon trong quá trình tổng hợp RNA thông tin trưởng thành (splice-site regions), hay các vị trí liên kết của các ribosome. Bên cạnh đó, các đột biến liên quan đến trình tự DNA như đột biến sai nghĩa (missense), đột biến vô nghĩa (nonsense) hay đột biến im lặng (silent) cũng tác động đến quá trình tổng hợp protein, trong đó dạng đột biến sai nghĩa có tính đóng góp hơn so với 2 dạng đột biến còn lại, nó làm thay đổi acid amin từ đó có thể ảnh hưởng hoặc không đến biểu hiện chức năng của protein, trong khi đột biến im lặng không làm thay đồi amino acid, tuy nhiên trong một số trường hợp chúng vẫn ảnh hưởng đến sự biểu hiện của kiểu hình bằng cách tăng hay làm chậm quá trình tổng hợp protein. Tỉ lệ đột biến của 2 giống lúa được thể hiện trong Bảng 3 , hầu hết tỉ lệ của đột biến sai nghĩa chiếm hơn $50 \%$ trong tổng số các dạng đột biến có mức ảnh hưởng đến chức năng, tuy nhiên tỉ lệ đột biến này ở giống Nếp Mỡ thấp hơn so với Đốc Phụng. 

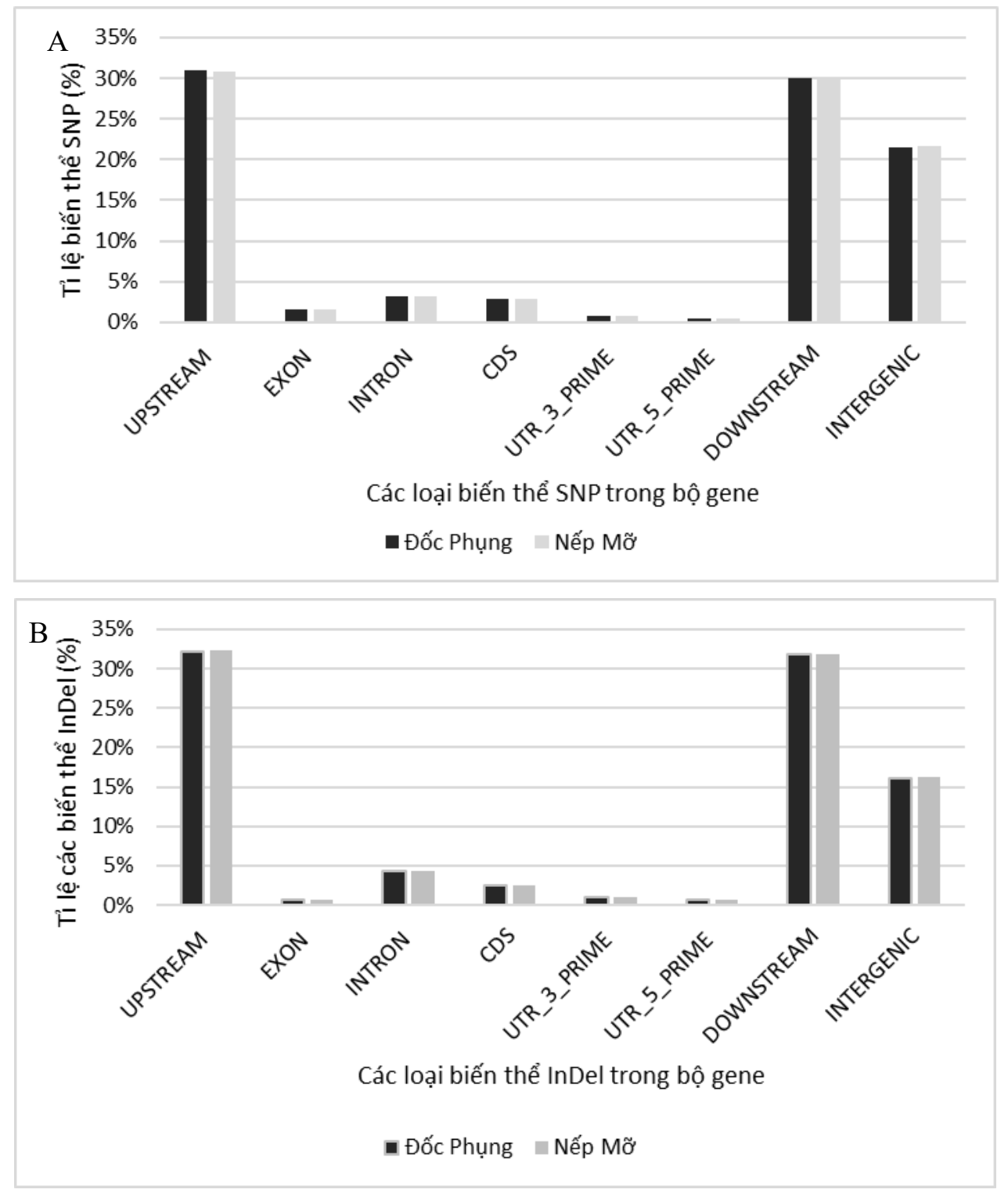

Hình 3. Tỉ lệ SNP (A) và InDels (B) xuất hiện ở các vị trí trong bộ gene

Bảng 3. Tỉ lệ các loại đột biến xuất hiện trên 2 giống lúa thí nghiệm

\begin{tabular}{lrrr}
\hline \multirow{2}{*}{ Tên giống } & \multicolumn{3}{c}{ Tỉ lệ đột biến (\%) } \\
\cline { 2 - 4 } & Sai nghĩa (Missense) & Vô nghĩa (Nonsense) & Im lặng (Silent) \\
\hline Đốc Phụng & 52,86 & 0,75 & 46,39 \\
Nếp Mỡ & 52,73 & 0,76 & 46,51 \\
\hline
\end{tabular}

3.2.2. Phân tích biến thể có trong các gene chịu mạn trên lúa

Phần lớn các biến thể xuất hiện nhiều ở vùng intergeneic, promoter và ít hơn ở vùng mã hóa DNA (Fuentes et al., 2019). Sự hiện diện của các biến thể ở vùng mã hóa exon được chú trọng hơn so với các vùng khác, mặc dù các biến thể trong vùng này không đủ để thiết lập bản đồ cho các đặc tính nông học phức tạp (Steri et al., 2018). Biến thể SNP/InDel hiện diện trên vùng promoter hay sự liên kết giữa các biến thể vùng này và vùng mã hóa đóng vai trò quan trọng ảnh hưởng đến các đặc điểm nông học trên cây trồng, tuy nhiên các hiểu biết về sự ảnh hưởng này vẫn chưa được hiểu rõ và chưa có nhiều báo cáo trên cây lúa (Wang et al., 2018; Wang et al., 
2019). Ngoài ra, các biến thể di truyền tại vùng unstranlated region (UTR) có thể thay đổi các yếu tố điều hòa từ đó tác động đến quá trình phiên mã của mRNA (Steri et al., 2018). Đáng chú ý hơn là có đến $3,7 \%$ biến thể xuất hiện ở vùng UTR theo các nghiên cứu liên quan đến Genome-wide association studies (GWAS) (Hindorff et al., 2009). Nhìn chung, mức độ phiên mã của gene có thể bị ảnh hưởng bởi SNP và InDel (Kreimer et al., 2012).
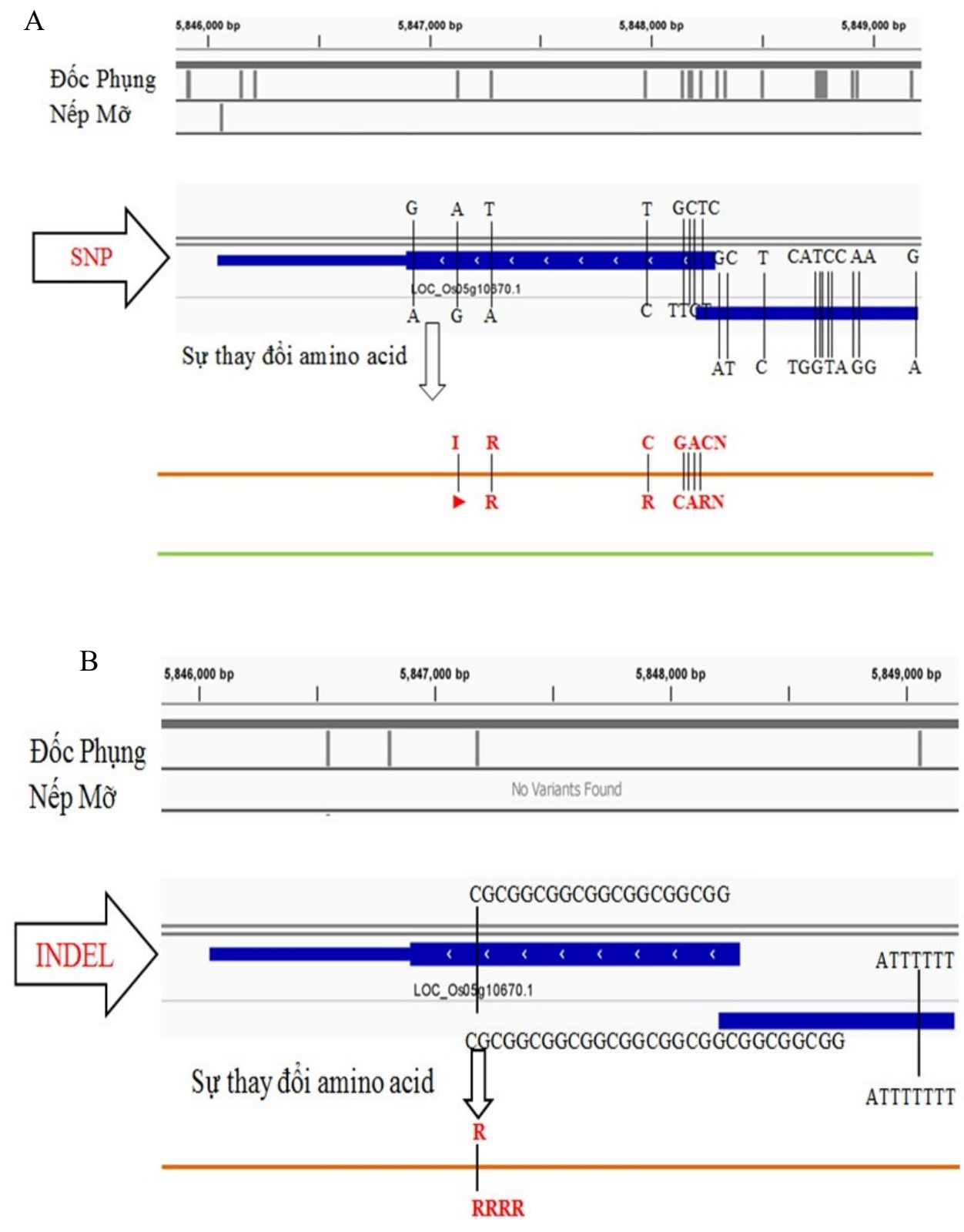

\section{Hình 4. Biến thể SNP (A) và InDel mất đi 3 amino acid Arginine (R) (B) ở giống lúa Đốc Phụng so với Nếp Mõ}

Trong nghiên cứu này, chương trình IGV được sử dụng để phát hiện vị trí của SNPs và InDels ở các gene có liên quan đến khả năng chống chịu mặn trên
12 NST đã được báo cáo trước đây (Naveed et al., 2018), từ đó so sánh sự khác nhau của biến thể trên cùng một gene của 2 giống lúa. Đặc biệt trong đó 
biến thể được phát hiện ở gene OsTZF1 (LOC_Os05g10670.1) mang chức năng điều hòa hậu phiên mã của nhóm gene phản ứng với stress sinh học và phi sinh học (stress với hạn, mặn cao) (Jan et al., 2013; Seong et al., 2020). Từ những nghiên cứu trên, ảnh hưởng của SNPs và InDel có ở gene này đã ảnh hưởng đến khả năng biểu hiện chức năng của gene rất quan trọng dưới tác động của mặn.

Khảo sát trên NST số 5 tại vùng gene $O s T Z F 1$ (LOC Os05g10670.1) của giống lúa Đốc Phụng cho thấy biến thể SNPs (Hình $4 \mathrm{~A}$ ) và InDels (Hình 4B) thể hiện sự khác biệt rõ ràng với giống Nếp Mỡ. Hình 4A cho thấy vùng gene này có sự hiện diện của đa hình ở Đốc Phụng là 16 vị trí (vùng exon: 7 vị trí) so với Nếp mỡ chỉ có 1 vị trí khi so sánh với bộ gene tham chiếu. Ngoài ra, Đốc Phụng có biến thể InDels trong vùng mã hóa exon tại vị trí 5.847.161$5.847 .180 \mathrm{bp}$ đã làm thay đổi chuỗi polypeptide bằng cách chèn thêm 3 amino acid arginine, trong khi đó không có ở giống Nếp Mỡ (Hình 4B). Như vậy, biến thể ở gene này có thể liên quan đến việc điểu hòa nhóm gene giúp cho giống Đốc Phụng chống chịu tốt với stress mặn, như những nghiên cứu trước (Jan et al., 2013; Naveed et al., 2018; Seong et al., 2020). Kết quả nghiên cứu này cho thấy có thể sử dụng đột biến mất 3 amino acid arginine của gene $O s T Z F 1$ được xem như là dấu chỉ thị phân tử là gene chức năng liên quan đến khả năng chống chịu mặn ở giống lúa Đốc Phụng nhằm phục vụ cho công tác chọn tạo giống lúa chống chịu mặn trong tương lai.

\section{KẾT LUẬN}

Tóm lại, nghiên cứu này cho thấy phương pháp tiếp cận gene chức năng dựa trên cơ sở giải trình tự bộ gene là một trong những kỹ thuật hiệu quả nhất để xác định các gene chứa các biến thể SNP và InDel liên quan đến các đặc điểm mong muốn. Việc phân tích biến thể xuất hiện ở giống lúa chịu mặn Đốc Phụng ở gene mục tiêu $O s T Z F 1$ là gene ứng viên cho điều hòa hoạt động các gene liện quan đển đặc tính chống chịu stress mặn là hợp lý. Tuy nhiên, cần có thêm bằng chứng để xác nhận chức năng của các gene này; chỉnh sửa bộ gene bằng một phương pháp hợp lý sẽ là cách tốt nhất để thực hiện điều này. Do đó, đề nghị tiếp tục dùng phương pháp chỉnh sửa bộ gene và biểu hiện gene để có kết luận chính xác về chức năng của gene này trên cây lúa.

\section{LỜI CẢM TẠ.}

Nghiên cứu được tài trợ bởi dự án Nâng cấp Trường Đại học Cần Thơ VN14-P6 (vốn vay ODA từ Chính phủ Nhật Bản).

\section{TÀI LIÊUU THAM KHẢO}

Barba, M., Czosnek, H., \& Hadidi, A. (2014). Historical perspective, development and applications of next-geneeration sequencing in plant virology. Viruses, 6(1), 106-136.

Barreiro, L. B., Laval, G., Quach, H., Patin, E., \& Quintana-Murci, L. (2008). Natural selection has driven population differentiation in modern humans. Nature Genetics, 40, 340-345.

Batley, J., Barker, G., O'Sullivan, H., Edwards, K. J., \& Edwards, D. (2003). Mining for single nucleotide polymorphisms and insertions/deletions in maize expressed sequence tag data. Plant physiology, 132, 84-91.

Bolser, D., Staines, D. M., Pritchard, E., \& Kersey, P. (2016). Ensembl Plants: Integrating Tools for Visualizing, Mining, and Analyzing Plant Geneomics Data. In: Edwards, D. (Ed.), Plant Bioinformatics: Methods and Protocols. Springer New York, New York, NY, pp. 115-140.

Chen, R., Cheng, Y., Han, S., Van Handel, B., Dong, L., Li, X., \& Xie, X. (2017). Whole geneome sequencing and comparative transcriptome analysis of a novel seawater adapted, saltresistant rice cultivar - sea rice $86 . B M C$ Geneomics, 18, 655.

Chen, S., Zhou, Y., Chen, Y., \& Gu, J. (2018). fastp: an ultra-fast all-in-one FASTQ preprocessor. Bioinformatics, 34, i884-i890.

Chu, J., Mohamadi, H., Warren, R. L., Yang, C., \& Birol, I. (2017). Innovations and challenges in detecting long read overlaps: an evaluation of the state-of-the-art. Bioinformatics (Oxford, England), 33, 1261-1270.

Doyle, J. J., and Doyle, J. J. (1990). Isolation of plant DNA from fresh tissue. Focus, 12, 13-15.

Fuentes, R. R., Chebotarov, D., Duitama, J., Smith, S., De la Hoz, J. F., Mohiyuddin, M., Wing, R. A., McNally, K. L., Tatarinova, T., Grigoriev, A., Mauleon, R., \& Alexandrov, N. (2019). Structural variants in 3000 rice geneomes. Geneome Research, 29, 870-880.

Hindorff, L. A., Sethupathy, P., Junkins, H. A., Ramos, E. M., Mehta, J. P., Collins, F. S., \& Manolio, T. A. (2009). Potential etiologic and functional implications of geneome-wide association loci for human diseases and traits. Proceedings of the National Academy of Sciences, 106, 9362-9367.

Huang, X., Lu, T., \& Han, B. (2013). Resequencing rice geneomes: an emerging new era of rice geneomics. Trends in genetics: TIG, 29, 225-232.

Islam, M. Z., Khalequzzaman, M., Prince, M., Siddique, M. A., Rashid, E., Ahmed, M., Pittendrigh, B. R., \& Ali, M. P. (2018). Diversity 
and population structure of red rice germplasm in Bangladesh. PLOS ONE, 13, e0196096.

Jain, M. (2012). Next-generation sequencing technologies for gene expression profiling in plants. Brief Funct Geneomics, 11, 63-70.

Jain, M., Moharana, K. C., Shankar, R., Kumari, R., \& Garg, R. (2014). Geneomewide discovery of DNA polymorphisms in rice cultivars with contrasting drought and salinity stress response and their functional relevance. Plant Biotechnology Journal, 12, 253-264.

Jan, A., Maruyama, K., Todaka, D., Kidokoro, S., Abo, M., Yoshimura, E., Shinozaki, K., Nakashima, K., \& Yamaguchi-Shinozaki, K. (2013). OsTZF1, a CCCH-Tandem Zinc Finger Protein, Confers Delayed Senescence and Stress Tolerance in Rice by Regulating Stress-Related Genes. Plant Physiology, 161, 1202-1216.

Kawahara, Y., de la Bastide, M., Hamilton, J. P., Kanamori, H., McCombie, W. R., Ouyang, S.,

Kawahara, Y., de la Bastide, M., Hamilton, J. P., Kanamori, H., McCombie, W. R., Ouyang, S., ... $\&$ Matsumoto, T. (2013). Improvement of the Oryza sativa Nipponbare reference genome using next generation sequence and optical map data. Rice, 6(1), 1-10.

Keel, B. N., and Snelling, W. M. (2018). Comparison of Burrows-Wheeler TransformBased Mapping Algorithms Used in HighThroughput Whole-Geneome Sequencing: Application to Illumina Data for Livestock Geneomes. Frontiers in genetics, 9, 35-35.

Khush, G. S. (1997). Origin, dispersal, cultivation and variation of rice. Springer, Dordrecht.

Kim, D., Langmead, B., \& Salzberg, S. L. (2015). HISAT: a fast spliced aligner with low memory requirements. Nature methods, 12, 357-360.

Kreimer, A., Litvin, O., Hao, K., Molony, C., Pe'er, D., \& Pe'er, I. (2012). Inference of modules associated to eQTLs. Nucleic acids research, 40(13), e98-e98.

Lakra, N., Kaur, C., Singla-Pareek, S. L., \& Pareek, A. (2019). Mapping the 'early salinity response'triggered proteome adaptation in contrasting rice genotypes using iTRAQ approach. Rice, 12(1), 1-22.

Li, H. (2011). A statistical framework for SNP calling, mutation discovery, association mapping and population genetical parameter estimation from sequencing data. Bioinformatics, 27(21), 2987-2993.

Li, H. (2014). Toward better understanding of artifacts in variant calling from high-coverage samples. Bioinformatics, 30(20), 2843-2851.
Li, H. (2016). Minimap and miniasm: fast mapping and de novo assembly for noisy long sequences. Bioinformatics, 32(14), 2103-2110.

Li, H., Handsaker, B., Wysoker, A., Fennell, T., Ruan, J., Homer, N., ... \& Durbin, R. (2009). The sequence alignment/map format and SAMtools. Bioinformatics, 25(16), 2078-2079.

Liu, W., Ghouri, F., Yu, H., Li, X., Yu, S., Shahid, M. Q., \& Liu, X. (2017). Geneome wide resequencing of newly developed Rice Lines from common wild rice (Oryza rufipogon Griff.) for the identification of NBS-LRR genes. PLOS ONE, 12, e0180662.

Lv, Q., Li, W., Sun, Z., Ouyang, N., Jing, X., He, Q., ... \& Yuan, D. (2020). Resequencing of 1,143 indica rice accessions reveals important genetic variations and different heterosis patterns. Nature communications, 11(1), 1-10.

Menguer, P. K., Sperotto, R. A., \& Ricachenevsky, F. K. (2017). A walk on the wild side: Oryza species as source for rice abiotic stress tolerance. Genetics and molecular biology, 40, 238-252.

Morgulis, A., Gertz, E. M., Schäffer, A. A., \& Agarwala, R. (2006). A fast and symmetric DUST implementation to mask low-complexity DNA sequences. Journal of Computational Biology, 13(5), 1028-1040.

Morton, B. R. (1995). Neighboring base composition and transversion/transition bias in a comparison of rice and maize chloroplast noncoding regions. Proceedings of the National Academy of Sciences, 92(21), 9717-9721.

Naveed, S. A., Zhang, F., Zhang, J., Zheng, T. Q., Meng, L. J., Pang, Y. L., ... \& Li, Z. K. (2018). Identification of QTN and candidate genes for salinity tolerance at the germination and seedling stages in rice by genome-wide association analyses. Scientific reports, 8(1), 1-11.

Nguyễn Thanh Tường, Nguyễn Tâm Đạo, Võ Công Thành \& Nguyễn Bảo Vệ. (2011). Tuyển chọn giống lúa cao sản chịu mặn cho vùng lúa - tôm tại tỉnh Bạc Liêu. Tạp chí Nông nghiệp và Phát triển Nông thôn, 12, 30-36.

Phạm Thanh Vũ, Võ Quang Minh, Vương Tuấn Huy và Phan Chí Nguyện. (2016). Tác động của mặn và ngập theo kịch bản biến đổi khí hậu đến tiềm năng thích nghi đất đai vùng ven biển Đồng bằng sông Cửu Long. Tạp chi Khoa hoc Truờng Đại học Cần Tho, Số chuyên đề: Nông nghiệp, 71-83.

Rahman, M. A., Thomson, M. J., Shah-E-Alam, M., de Ocampo, M., Egdane, J., \& Ismail, A. M. (2016). Exploring novel genetic sources of salinity tolerance in rice through molecular and physiological characterization. Annals of botany, 117(6), 1083-1097. 
Robinson, J. T., Thorvaldsdóttir, H., Winckler, W., Guttman, M., Lander, E. S., Getz, G., \& Mesirov, J. P. (2011). Integrative genomics viewer. Nature biotechnology, 29(1), 24-26.

Seong, S. Y., Shim, J. S., Bang, S. W., \& Kim, J. K. (2020). Overexpression of OsC3H10, a CCCH-zinc finger, improves drought tolerance in rice by regulating stress-related genes. Plants, 9(10), 1298.

Steri, M., Idda, M. L., Whalen, M. B., \& Orrù, V. (2018). Genetic variants in mRNA untranslated regions. Wiley Interdisciplinary Reviews. $R N A, 9(4), \mathrm{e} 1474$.

Subbaiyan, G. K., Waters, D. L. E., Katiyar, S. K., Sadananda, A. R., Vaddadi, S., \& Henry, R. J. (2012). Geneome-wide DNA polymorphisms in elite indica rice inbreds discovered by wholegeneome sequencing. Plant Biotechnology Journal, 10, 623-634.

Subudhi, P. K., Shankar, R., \& Jain, M. (2020). Whole geneome sequence analysis of rice geneotypes with contrasting response to salinity stress. Scientific Reports, 10, 21259.

Tam, N. T. (2019). The geneome constitution of rice resources in the Mekong Delta and their association with salinity stress (Doctoral dissertation). Hokkaido University.

Thorvaldsdóttir, H., Robinson, J. T., \& Mesirov, J. P. (2013). Integrative Genomics Viewer (IGV): high-performance genomics data visualization and exploration. Briefings in bioinformatics, 14(2), 178-192.

Tin, H. Q., Loi, N. H., Labarosa, S. J. E., McNally, K. L., McCouch, S., \& Kilian, B. (2021). Phenotypic response of farmer-selected CWRderived rice lines to salt stress in the Mekong Delta. Crop Science, 61(1), 201-218.

Wakeley, J. (1996). The excess of transitions among nucleotide substitutions: new methods of estimating transition bias underscore its significance. Trends in ecology \& evolution, 11(4), 158-162.

Wang, J., Zhu, J., Zhang, Y., Fan, F., Li, W., Wang, F., ... \& Yang, J. (2018). Comparative transcriptome analysis reveals molecular response to salinity stress of salt-tolerant and sensitive genotypes of indica rice at seedling stage. Scientific reports, 8(1), 1-13.

Wang, P., Xiong, Y., Gong, R., Yang, Y., Fan, K., \& $\mathrm{Yu}, \mathrm{S}$. (2019). A key variant in the cis-regulatory element of flowering gene Ghd8 associated with cold tolerance in rice. Scientific reports, 9(1), 1-14.

Yuan, J., Wang, X., Zhao, Y., Khan, N. U., Zhao, Z., Zhang, Y., ... \& Li, Z. (2020). Genetic basis and identification of candidate genes for salt tolerance in rice by GWAS. Scientific reports, 10(1), 1-9. 